\begin{tabular}{|c|c|c|c|}
\hline $\begin{array}{l}\text { A CASE } \\
\text { STUdy }\end{array}$ & $\begin{array}{r}\text { ADVANCE RESEARC } \\
\text { Volume } 7 \mid \text { Issue } 1 \mid\end{array}$ & $\begin{array}{l}\text { OCIAL SCIENCE } \\
\text { N-2231-6418 }\end{array}$ & \\
\hline $0=$ & DOI: 10.15740/HAS/ARJSS/7.1/136-141 & Visit us : www.researchjournal.co.in & \\
\hline
\end{tabular}

\title{
Social diversity among the tribal students in Kerala: A sociological study
}

Grace Varghese

Department of Sociology, Mahatma Gandhi University, KOTTAYAM (KERALA) INDIA

(Email: gracejohnsonsalu@ yahoo.co.in)

\section{ARTICLE INFO :}

Received : 21.12 .2015

Accepted : 24.05.2016

\section{KEY WORDS :}

Diversity, Education, Kerala, Social, Students, Tribe

\section{HOW TO CITE THIS ARTICLE :}

Varghese, Grace (2016). Social diversity among the tribal students in Kerala: A sociological study. Adv. Res. J. Soc. Sci., 7 (1) : 136-141, DOI: 10.15740/HAS/ ARJSS/7.1/136-141.

\section{ABSTRACT}

Tribal students come from very poor socio-economic background in comparison to the general population. Most of necessary them live in remote rural areas and they study comparatively poor atmosphere lacking competent teachers physical facilities better social environment etc. The Tribal people in Kerala are educationally and, financially, socially deprived classes. Some argue that this local culture is an obstacle to the development of the tribes and that they try to snatch it away from them by imposing the culture of the urban areas. The investigator noted that tribal children find it difficult to cope with school environment which represents to them a totally alien culture. Moreover a new approach towards the tribal people is expected by bringing out the socio-educational problems of the tribes and the attain of the government educationalist and other social workers is solicited for the improvement of tribal education. 